\title{
Thermotolerance, Survival, and Stability of Lactic Acid Bacteria After Spray Drying as Affected by the Increase of Growth Temperature
}

\author{
Fan $\mathrm{Hao}^{1} \cdot \mathrm{Nan} \mathrm{Fu}^{1}$ (D) Hamadel Ndiaye ${ }^{1} \cdot$ Meng Wai Woo $^{2} \cdot$ Romain Jeantet $^{1,3} \cdot$ Xiao Dong Chen $^{1}$ \\ Received: 26 June 2020 / Accepted: 15 December 2020 \\ (C) The Author(s), under exclusive licence to Springer Science+Business Media, LLC part of Springer Nature 2021
}

\begin{abstract}
Microencapsulation of lactic acid bacteria (LAB) via spray drying differs from that of common bioactive substances in that the intrinsic stress tolerance of cells can be modulated to improve cell survival. In this study, elevated growth temperatures that were $3-5{ }^{\circ} \mathrm{C}$ above the standard conditions were used to culture Lactococcus lactis subsp. cremoris, Lactobacillus rhamnosus GG (LGG), and Lactobacillus acidophilus for spray drying. The heat-adapted cultures showed lower bacterial population than the controls by $0.45 \mathrm{log}$ at stationary growth phase and produced lactobacilli cells with elongated shape, while their metabolic activities were maintained similar to the controls. Heat-adapted L. cremoris and LGG demonstrated increases in survival by $0.7-$ $1.5 \log$ and $0.3 \log$, respectively, after heat treatment at $60{ }^{\circ} \mathrm{C}$. The thermotolerance of L. acidophilus grown at $42{ }^{\circ} \mathrm{C}$ was dependent on growth phase, and the culture entered death phase within $24 \mathrm{~h}$ of incubation. The survival of heat-adapted $L$. cremoris and L. acidophilus after spray drying was increased by $21.0 \%$ and $13.7 \%$, respectively, whereas the increase shown by LGG was relatively insignificant $(9.9 \%)$. Spray-dried powders containing heat-adapted cells showed substantial reduction of viability at the first week of storage, reaching $1.03-1.23 \mathrm{log}$, compared to $0.87-0.90 \mathrm{log}$ of reduction shown by the controls. The findings demonstrated that strain-specific cellular response toward variations in growth conditions is crucial to the intrinsic properties of LAB and to cell survival during spray drying and storage. Controlling cellular response is one of the key factors in developing a viable spray drying scheme for active LAB.
\end{abstract}

Keywords Active dry probiotics $\cdot$ Lactobacillus rhamnosus GG $\cdot$ Pre-adaptation $\cdot$ Probiotics powder $\cdot$ Storage stability $\cdot$ Stress tolerance

\section{Introduction}

Several lactic acid bacteria (LAB) strains are reputed probiotics when orally administrated in a viable form with adequate amount (Forster and Lawley 2015; Vasiljevic and Shah 2008). These microorganisms have attracted growing

$\mathrm{Nan} \mathrm{Fu}$

nan.fu@suda.edu.cn

1 FoodPRINT International Associated Laboratory INRAE, School of Chemical and Environmental Engineering, College of Chemistry, Chemical Engineering and Materials Science, Soochow University, Suzhou, Jiangsu 215123, China

2 Department of Chemical \& Materials Engineering, The University of Auckland, 5-7 Grafton Road, Auckland 1010, New Zealand

3 STLO, INRAE, Institut Agro, 35042 Rennes, France attention in recent years both as functional foods and as potential pharmaceutics (Bansal and Garg 2008; Kavitake et al. 2018). In food and pharmaceutical applications, dry bacteria powder is a convenient product form for transportation and incorporation into other processing operations such as mixing and tableting (Fu et al. 2018; Peighambardoust et al. 2011). Compared to liquid product, it has advantages in the long-term maintenance of the activity of bio-active components, which can effectively prolong the shelf-life of products (Rabaioli Rama et al. 2020; Schutyser et al. 2012).

Spray drying can rapidly convert liquid feed to powder, with a high production rate up to several tonnes per hour (Jin and Chen 2010). It is capable of processing heatsensitive material, as the temperature of atomized droplets could be controlled at a relatively low level by evaporative cooling effect (Fu et al. 2011). It is a common approach utilized for the microencapsulation of bio-active substances to protect them from environmental stresses (Fu et al. 2020; Oliveira et al. 2018). Spray drying has been actively 
investigated for its potential in producing active probiotics powder, in which bacterial cells are encapsulated by protectant matrix (Kavitake et al. 2018; Schutyser et al. 2012). In such a process, the processing procedure must be carefully controlled to minimize the loss of bacterial viability. Unoptimized spray drying conditions may expose bacterial cells to high temperature and rapid dehydration, causing modifications of the structure of sensitive proteins as well as alterations of the physical state of lipids on cellular membrane (Fritzen-Freire et al. 2013; Gul and Atalar 2019; Leuenberger et al. 2017). To protect the viability of LAB cells during spray drying, various approaches have been proposed. Microcapsules with novel structure have been designed to improve the stability of cells toward heat treatment, in vitro digestion, and storage (ArslanTontul and Erbas 2017; Zhao et al. 2018). The formulation of protectant proves to be a crucial factor influencing the survival of spray-dried cells (Liu et al. 2018b; Su et al. 2019), and the underlying protective mechanisms for a variety of reagents have been explored for developing high-performance protectant formulation.

As living microorganisms, LAB cells differ from other bioactive substances such as vitamins and fatty acids, in that they can respond to environmental stresses, and can be injured and repair the injury to continue multiplying. Previous studies showed that the intrinsic stress tolerance of a given LAB strain may vary depending on growth conditions and specific treatments of cells. Adding sucrose to growth medium could improve the thermotolerance of cells and increase the survival of cells in subsequent vacuum drying (Silva et al. 2004; Tymczyszyn et al. 2007). Subjecting cells to a sublethal heat treatment after the standard cultivation procedure not only enhanced the thermotolerance of cells but also exerted crossprotective effects toward other stresses, such as salt and bile (Desmond et al. 2001). Huang et al. (2016a) found that culturing LAB strains with concentrated sweet whey effectively improved the survival of spray-dried cells. The mechanism was attributed to $\mathrm{LAB}$ cells acquiring tolerance to multiple stresses under the hyperosmotic growth condition, by the expression of stress proteins and the intracellular accumulation of compatible solutes (Huang et al. 2016b).

With regard to the industrial production of LAB powder, the induction of cell stress tolerance by altering growth conditions is more cost-effective than incorporating a preadaptation procedure after the cultivation process of cells. It saves a processing step, and also avoids the possible loss of cell viability during the sublethal treatment. To induce the adaptive response of cells, culturing lactobacilli under a variety of sublethal conditions has been attempted, including the use of high and low temperature, the variation of $\mathrm{pH}$, oxygenation and osmotic pressure, as well as the addition of inhibitory substances such as bile salts (Dijkstra et al. 2014; Gaucher et al. 2020; Settachaimongkon et al. 2015). Increasing the growth temperature may be a straightforward approach to enhance the thermotolerance of cells. Dijkstra et al., (2014) reported that Lactococcus lactis grown at an elevated temperature exhibited the expression of stress genes, which were positively correlated with the increased robustness of cells toward heat and oxidative stresses. Cebrián et al. (2019) showed that a high growth temperature was associated with an increase in the rigidity of cellular membrane of Staphylococcus aureus, contributing to improved heat stability. As heat stress is generally acknowledged as a major stress during spray drying (Liu et al. 2018a; Perdana et al. 2013), culturing LAB cells at elevated growth temperatures may be a useful processing strategy to increase the survival of spray dried LAB. However, the influence of growth temperature on LAB cells could vary among individual strains; the extent of the effect of elevated growth temperature on LAB survival during spray drying warrants detailed investigation.

In this study, three LAB strains, namely Lactococcus lactis ssp. cremoris, Lactobacillus acidophilus NCFM, and Lactobacillus rhamnosus GG were cultured both under standard growth conditions and under increased growth temperatures by $3-5{ }^{\circ} \mathrm{C}$. The objective was to examine the capability of the modified cultivation approach to improve the viability retention of $\mathrm{LAB}$ cells during both spray drying and storage. The protectant used in the spray drying experiments was reconstituted skim milk (RSM) at $30 \mathrm{wt} \%$, which was one of the most reputed protectants for spray drying of LAB (Dimitrellou et al. 2016; Gong et al. 2019; Gul and Atalar 2019). The activity of fresh culture, the thermotolerance of cells, and the stability of spray-dried cells were investigated.

\section{Materials and Methods}

\section{Microorganisms}

Lactococcus lactis subsp. cremoris (CGMCC 1.3991 or ATCC 19257) was cultured on M17 agar plates composed of M17 broth (Oxoid CM0817, Oxoid Ltd., UK) and $12.0 \mathrm{~g} /$ $\mathrm{L}$ agar. Incubation was carried out at $30{ }^{\circ} \mathrm{C}$ for $48 \mathrm{~h}$. Lactobacillus acidophilus NCFM and Lactobacillus rhamnosus GG (LGG) were cultured on MRS agar plates (Oxoid CM1175) at $37^{\circ} \mathrm{C}$ for $48 \mathrm{~h}$. The cultures were stored at $4{ }^{\circ} \mathrm{C}$. Subculture to fresh medium was performed every 7 days.

\section{Growth Conditions of LAB Cells}

To prepare the inoculum of each strain, a single colony on the culture maintenance plate was used to inoculate fresh growth medium of $10 \mathrm{~mL}$. Two bottles of M17 broth were inoculated with $L$. cremoris. Incubation was performed at the standard growth temperature of $30^{\circ} \mathrm{C}$ for the first bottle and elevated growth temperature of $33^{\circ} \mathrm{C}$ for the second bottle. After $12 \mathrm{~h}$, 
each of the inocula was transferred to fresh M17 broth at an inoculum size of $1 \%(\mathrm{v} / \mathrm{v})$. The fermentation broth for biomass production was incubated at the same temperature to the corresponding inoculum for $24 \mathrm{~h}$. The use of $33{ }^{\circ} \mathrm{C}$ as elevated temperature for growing L. cremoris was based on the results of preliminary experiments.

The inoculum medium of LGG was MRS, and incubation was performed at 37 and $42{ }^{\circ} \mathrm{C}$, respectively. For biomass production, fresh MRS broth was inoculated with the 12-h culture, and then incubated at the same temperature to its inoculum for $24 \mathrm{~h}$. Other conditions were the same to the L. cremoris culture. L. acidophilus was also cultured in MRS broth at 37 and $42{ }^{\circ} \mathrm{C}$. All conditions were the same to the LGG culture, except that the fermentation for biomass production at $37{ }^{\circ} \mathrm{C}$ was carried out for $24 \mathrm{~h}$, and that at $42{ }^{\circ} \mathrm{C}$ was carried out for $12 \mathrm{~h}$, respectively.

A total of six LAB cultures were prepared, namely two $L$. cremoris cultures after incubation at 30 and $33{ }^{\circ} \mathrm{C}$ for $24 \mathrm{~h}$, two LGG cultures after incubation at 37 and $42{ }^{\circ} \mathrm{C}$ for $24 \mathrm{~h}$, L. acidophilus culture grown at $37{ }^{\circ} \mathrm{C}$ for $24 \mathrm{~h}$, and L. acidophilus culture grown at $42{ }^{\circ} \mathrm{C}$ for $12 \mathrm{~h}$. By the end of incubation, each culture was at stationary growth phase according to growth curves measured with optical density method and plate count method in preliminary experiments ( $\mathrm{Su}$ et al. 2019; Suo et al. 2020). The heat-adapted culture and control culture of each strain were subjected to characterization analyses, heat treatment, and spray drying as shown in Fig. 1. All growth media used to culture LAB cells were sterilized at $121{ }^{\circ} \mathrm{C}$ for $15 \mathrm{~min}$.

\section{Metabolic Activity of LAB Cultures}

The metabolic activity of the six LAB cultures was examined using the iodonitrotetrazolium chloride (INT) assay as described by Ulmer et al. (2000) with appropriate modifications. Each culture was centrifuged at $8000 \mathrm{rpm}, 4^{\circ} \mathrm{C}$ for $10 \mathrm{~min}$ to collect cells. The cell pellet was washed with phosphate buffer containing glucose (PBG, consisting of $50 \mathrm{mM}$ of $\mathrm{H}_{2} \mathrm{KPO}_{4}$, $0.83 \mathrm{mM}$ of $\mathrm{MgSO}_{4}, 0.33 \mathrm{mM}$ of $\mathrm{MnSO}_{4}$, and $22.2 \mathrm{mM}$ of glucose, $\mathrm{pH}$ 6.5) and resuspended in PBG. The volume of PBG used to resuspend the centrifuged cell pellet was the same to the fresh culture, so the viable cell count of the resuspended culture remained the same to the fermentation broth at the stationary growth phase. INT (I6069, Macklin Biochemical Co. Ltd., Shanghai, China) was dissolved in PBG solution to prepare stock solution of $4 \mathrm{mM}$. For INT assay, LAB cell suspension was mixed with the INT stock solution at a volume ratio of 1:1. Active cells could reduce the colorless INT and generate red formazan dye as product. After reacting for $10 \mathrm{~min}$, the color density of the reaction solution was read at $595 \mathrm{~nm}$ using a microplate reader (Molecular Devices M5, USA).

\section{Heat Treatment Experiment}

The six LAB cultures were subjected to heat treatment immediately after the incubation was terminated. Heat challenge was applied to $5 \mathrm{~mL}$ of culture contained in centrifuge tubes of $10 \mathrm{~mL}$, using a water bath at $60^{\circ} \mathrm{C}$. The viable cell counts in the fresh culture and in cultures after different time of heat treatment were analyzed with the standard plate count method.

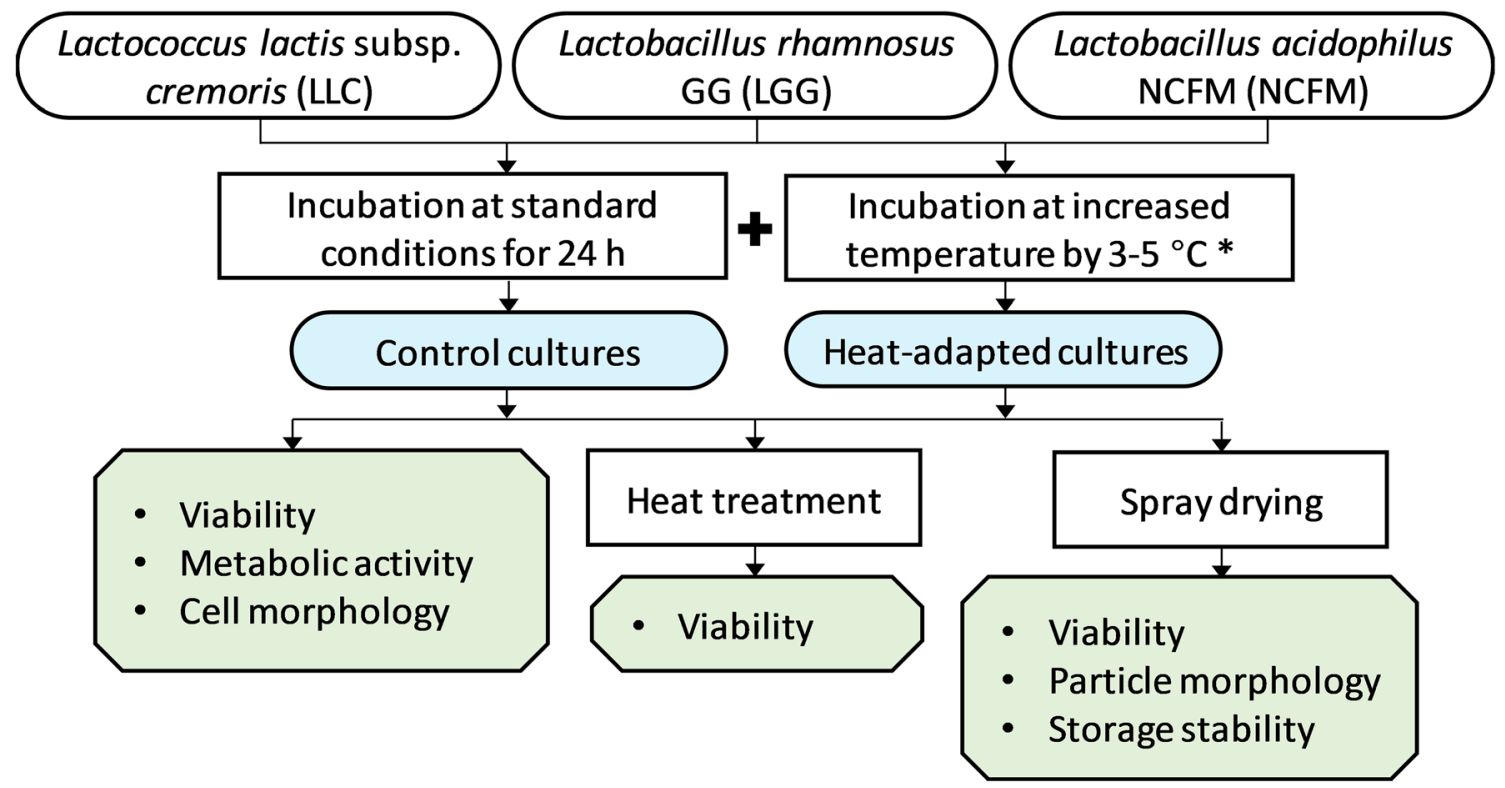

Fig. 1 Experimental procedures to prepare the heat-adapted culture and control culture of three LAB strains, and the subsequent characterization analyses, heat treatment, and spray drying. * Heat-adapted LLC and LGG

cultures were grown at 33 and $42{ }^{\circ} \mathrm{C}$, respectively, for $24 \mathrm{~h}$, while heatadapted NCFM culture was grown at $42^{\circ} \mathrm{C}$ for $12 \mathrm{~h}$ 
L. cremoris samples were heated for 2, 4, 6, 8, 10, 12, and 14 min, whereas LGG samples were heated for 6 min and $L$. acidophilus $4 \mathrm{~min}$. The heated centrifuge tubes were taken out from the water bath after the designated time, and cooled with tap water for 3-4 min. Each sample was serially diluted with a dilution factor of $1 / 10$, using $0.5 \%(\mathrm{w} / \mathrm{v})$ peptone solution as diluent. At appropriate dilution factors, $0.1 \mathrm{~mL}$ of the diluted sample was spread onto the corresponding agar plate used to grow the strain. The spread plates were incubated at 30 ${ }^{\circ} \mathrm{C}$ for L. cremoris and $37{ }^{\circ} \mathrm{C}$ for LGG and L. acidophilus, respectively, for $48 \mathrm{~h}$ before colonies were counted.

\section{Preparation of Bacterial Suspension for Spray Drying}

Skim milk powder (Devondale, Australia) was dissolved in sterile deionized water at $30 \mathrm{wt} \%$ to prepare the protectant for spray drying. The reconstituted skim milk (RSM) was homogenized with a high-pressure homogenizer (ATS Engineering Inc., China) at $800 \pm 50$ bar for 3 passes, prior to mixing with LAB cells. Fresh LAB culture was centrifuged at $8000 \mathrm{rpm}, 4$ ${ }^{\circ} \mathrm{C}$ for $10 \mathrm{~min}$. The cell pellet was washed with $0.5 \%(\mathrm{w} / \mathrm{v})$ sterilized peptone solution and then centrifuged again at the same condition. The resulting cell pellet was re-suspended in the homogenized RSM, and the volume of RSM was controlled at 5 or 10 times the volume of the fresh culture (the ratio of culture volume to protectant volume was 1:5 or 1:10), to adjust viable cell concentration to around $1 \times 10^{8} \mathrm{cfu} / \mathrm{g}$ of dry solids mass in the feed of spray drying.

\section{Spray Drying Experiment}

Spray drying of the LAB-containing milk was performed with a micro-fluidic jet spray dryer (MFJSD, Model MDSD-III, Nantong Dong-Concept New Material Technology Ltd., Jiangsu Province, China), following experimental procedure described in previous studies (Su et al. 2019; Tian et al. 2014). The conditions were inlet temperature of $100 \pm 3{ }^{\circ} \mathrm{C}$, outlet temperature of $58 \pm 3{ }^{\circ} \mathrm{C}$, and a nozzle with orifice of $75 \mu \mathrm{m}$. Prior to each spray drying experiment, the spray dryer was preheated for $2.5 \mathrm{~h}$ to stabilize the temperature inside. The spray drying experiment of each strain was completed in $2 \mathrm{~h}$ after the feed was prepared, to minimize the fermentation of milk by LAB.

The moisture content of spray-dried powder and the remaining viability of LAB were analyzed on the same day of spray drying. Experimental procedures were similar to the study of Su et al. (2019), with minor modifications on the reconstitution method of the dried powder. The moisture content of the powder and the solids content of the feed were determined using a gravimetric method, whereby the samples were mixed with pre-dried sand and subjected to oven drying at $104{ }^{\circ} \mathrm{C}$ for $24 \mathrm{~h}$ to determine weight difference. For the plate count assay, spray-dried powder was reconstituted by dissolving $0.1 \mathrm{~g}$ of powder in $10 \mathrm{~mL}$ of peptone solution. The viable cell counts in the reconstituted milk and in the feed were enumerated following the procedure described above. The corresponding viability of LAB in spray-dried powder $\left(N_{p}\right)$ and in the feed $\left(N_{0}\right)$ was standardized as cfu/g dry solids mass, and the survival ratio was calculated as $N_{p} / N_{0}$ (Su et al. 2019). The residual powder was stored in a desiccator at $4{ }^{\circ} \mathrm{C}$ for scanning electron microscopy (SEM) analysis and storage test.

\section{Scanning Electron Microscopy Analysis}

SEM was utilized to examine the morphology of LAB cells cultured at different growth temperatures, the particle morphology of LAB powders, and the morphology of cells encapsulated in the milk matrix of the powders. For fresh LAB cultures, the cell pellet obtained by centrifugation was first washed with sterile saline solution $(0.85 \%$ (w/v) $\mathrm{NaCl}$ solution) and then resuspended in $2.5 \%(\mathrm{w} / \mathrm{v})$ glutaraldehyde. The cell suspension was kept at $4{ }^{\circ} \mathrm{C}$ for $2 \mathrm{~h}$ to fix the cells. After that, LAB cells were collected by centrifugation, followed by washing with sterile deionized water three times. The resulting cell pellet was dehydrated with a grade series of ethanol solution, namely $30 \%, 50 \%, 70 \%, 80 \%, 90 \%$, and $100 \%(\mathrm{v} / \mathrm{v})$, for $10 \mathrm{~min}$ at each grade. The dehydration was ended with repeated treatments in $100 \%$ ethanol for another three times, $15 \mathrm{~min}$ each time. The dehydrated cells were placed in a vacuum oven at $40{ }^{\circ} \mathrm{C}$ for 2 days to allow the ethanol to evaporate. Then, the LAB cells were carefully mounted to an aluminum stub using conducting carbon tape.

LAB powders produced by the above spray drying experiments were directly loaded to a sample stub for SEM observation. To examine the morphology of LAB cells embedded in the milk matrix, cells collected from fresh culture were spray dried with $1 \mathrm{wt} \%$ skim milk and the viable cell concentration in the feed was kept the same to the fresh culture (the ratio of culture volume to protectant volume was 1:1). Spray drying conditions were the same as described above. Dried powders were broken with a tiny hammer to expose inner structure, before loaded to the sample stub.

All samples were sputter-coated with platinum/gold to produce a conductive surface for SEM observation. Secondary electron SEM images for LAB particle morphology were recorded using a Hitachi SU1510 (Hitachi Ltd., Japan), and images for LAB cell morphology were recorded using a Hitachi S4700.

\section{Stability of Spray-Dried LAB Cells During Storage}

LAB powders stored at $4{ }^{\circ} \mathrm{C}$ were analyzed for the residual viability of $\mathrm{LAB}$ cells on days $7,14,45,83$, and 110 after spray drying. The powders were reconstituted, and LAB viability was analyzed with the plate count method, following the 
same procedure described above. The viable cell count in cfu/ $\mathrm{mL}$ was compared to the result on day 0 , to calculate changes in $\mathrm{LAB}$ viability during storage.

\section{Statistical Analysis}

The heat treatment and spray drying experiments were independently carried out three or four times, with freshly prepared $\mathrm{LAB}$ cultures each time. The reported results are average values \pm standard deviation. Metabolic activity, SEM observation, and storage tests were independently performed twice to ensure the reproducibility of the results. Statistical analyses were performed using the Student's $t$ test with 95\% confidence interval (Excel 2016, Microsoft Corporation, USA).

\section{Results}

\section{The Activity and Morphology of LAB Strains Grown at Different Temperatures}

The viable cell count and metabolic activity of $L$. cremoris, LGG, and L. acidophilus grown at the standard and the elevated temperatures are shown in Figs. 2 and 3, respectively. All cultures, including L. acidophilus grown at $42^{\circ} \mathrm{C}$ for $12 \mathrm{~h}$, reached the stationary growth phase when the incubation was terminated. L. cremoris and L. acidophilus cultures grown at the elevated temperatures showed fewer viable cells than the control cultures grown at the standard temperatures $(p<0.05$, Fig. 2). The viable cell concentration in the heat-adapted $L$.

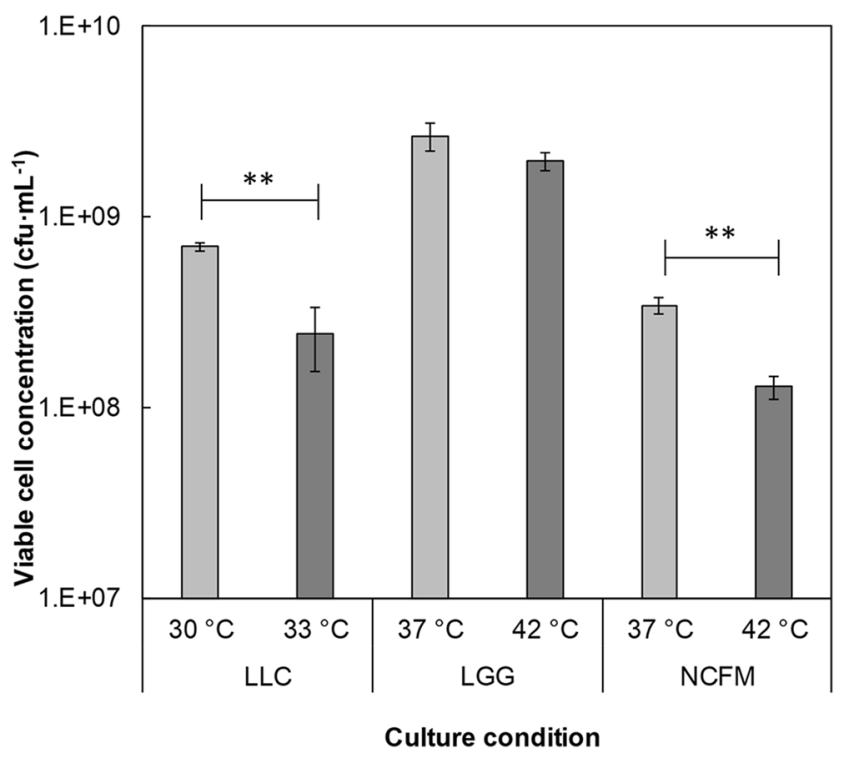

Fig. 2 The viable cell count of three LAB strains at the stationary growth phase, when incubation was carried out at the standard $\left(30\right.$ and $\left.37^{\circ} \mathrm{C}\right)$ and elevated temperatures ( 33 and $42^{\circ} \mathrm{C}$ ). LLC Lactococcus lactis ssp. cremoris, LGG Lactobacillus rhamnosus GG, NCFM Lactobacillus acidophilus NCFM. ** indicate that the two values are significantly different $(p<0.05)$ cremoris culture and the corresponding control culture was $2.47 \times 10^{8}$ and $6.99 \times 10^{8} \mathrm{cfu} / \mathrm{mL}(8.34$ and $8.84 \log \mathrm{cfu} /$ $\mathrm{mL}$ ), respectively, and that of $L$. acidophilus cultures was $1.29 \times 10^{8}$ and $3.46 \times 10^{8} \mathrm{cfu} / \mathrm{mL}(8.10$ and $8.53 \log \mathrm{cfu} /$ $\mathrm{mL}$ ), respectively, indicating a decrease of bacterial viability by around $0.45 \log$ when the growth temperature was increased by $3-5^{\circ} \mathrm{C}$. For LGG, the amount of viable cells after incubated at $42{ }^{\circ} \mathrm{C}$ for $24 \mathrm{~h}$ was consistently lower than that at $37^{\circ} \mathrm{C}$ in individual experiments, with average viability of 1.98 $\times 10^{9}$ and $2.66 \times 10^{9} \mathrm{cfu} / \mathrm{mL}(9.28$ and $9.39 \mathrm{log} \mathrm{cfu} / \mathrm{mL})$, respectively. However, with triplicate experiments, the difference remained insignificant $(p>0.1)$.

The metabolic activity of each LAB strain at the two growth temperatures was similar (Fig. 3), although the bacterial population of the heat-adapted cultures tended to be lower than that of the corresponding control cultures. All six cultures quickly reduced INT to insoluble red formazan in $10 \mathrm{~min}$ (Fig. $3 a)$, indicating high robustness. The results suggested that the
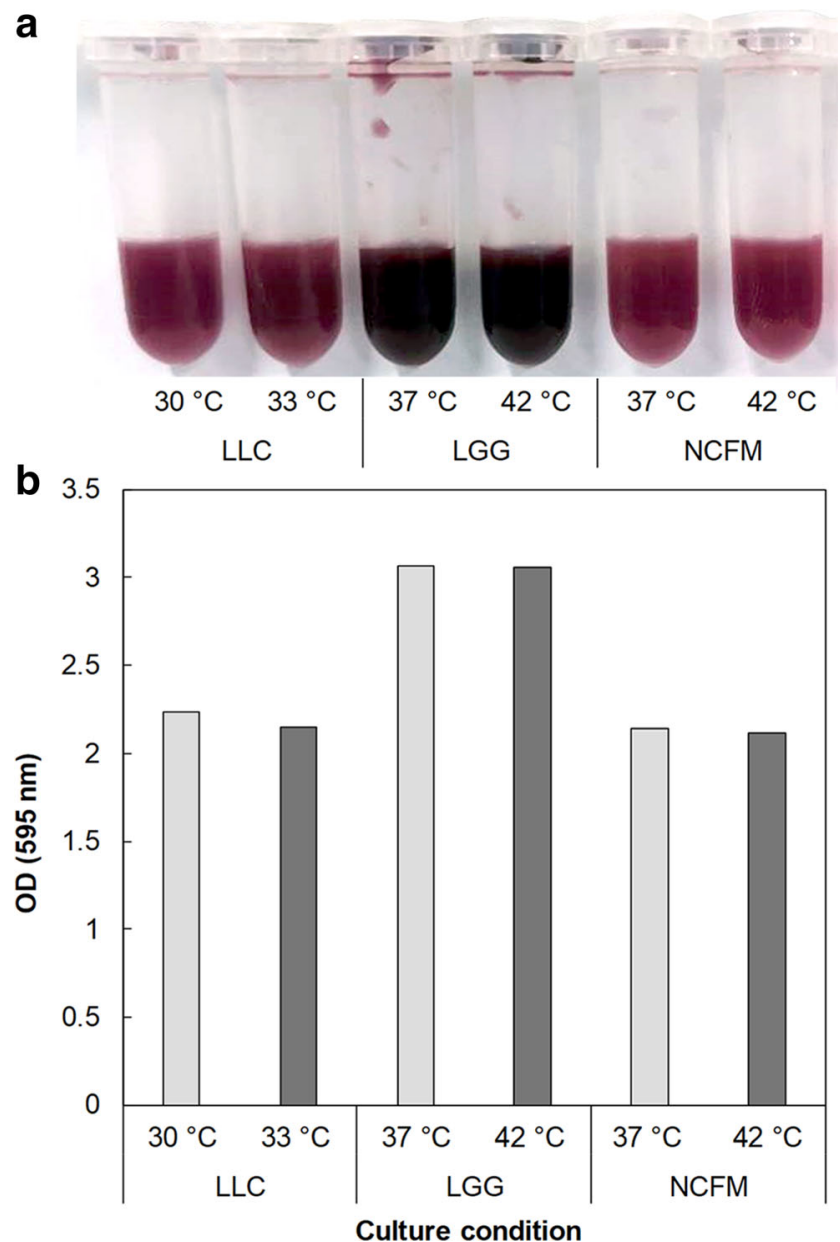

Fig. 3 The metabolic activity of three LAB strains at the stationary growth phase, when incubation was carried out at the standard (30 and $37^{\circ} \mathrm{C}$ ) and elevated temperatures $\left(33\right.$ and $42^{\circ} \mathrm{C}$ ). a Color change and b absorbance of each culture analyzed with the iodonitrotetrazolium chloride (INT) assay. LLC Lactococcus lactis ssp. cremoris, LGG Lactobacillus rhamnosus GG, NCFM Lactobacillus acidophilus NCFM 
heat-adapted cultures, albeit containing fewer cells in the fermentation broth, showed similar efficiency in generating electrons during metabolism to the control cultures. Note that among the three LAB strains, LGG showed the highest viable cell count of $1-2 \times 10^{9} \mathrm{cfu} / \mathrm{mL}$ (9.28-9.39 $\mathrm{log} \mathrm{cfu} / \mathrm{mL}$; Fig. 2), and the corresponding color density after reaction with INT for 10 min was remarkably higher than that shown by $L$. cremoris and L. acidophilus, whose viable cell count ranged between $1 \times 10^{8}$ and $7 \times 10^{8} \mathrm{cfu} / \mathrm{mL}(8.10-8.84 \log \mathrm{cfu} / \mathrm{mL})$. The larger bacterial population may help generate higher amount of electrons per unit time, leading to better efficiency of INT reduction.

The three strains showed characteristic cellular shape and arrangement when examined with SEM (Fig. 4). L. cremoris was typical coccus with size perceptibly smaller than $1 \mu \mathrm{m}$ (Fig. 4A, a). LGG was short rods, and the length of each cell was between 1 and $2 \mu \mathrm{m}$ (Fig. 4C, c). L. acidophilus was also rods, but its cells were considerably longer than that of LGG (Fig. 4E, e). All three strains formed characteristic chain arrangement as expected for lactic acid bacteria. Notably, at higher growth temperature of $42{ }^{\circ} \mathrm{C}$, both LGG and $L$. acidophilus cells were elongated. The size of heat-adapted LGG cells was increased to $2-4 \mu \mathrm{m}$ (Fig. 4D, d), whereas for L. acidophilus, not only the length of individual cells was extended, but the cellular chains were also lengthened, forming fibrous structure (Fig. 4F).
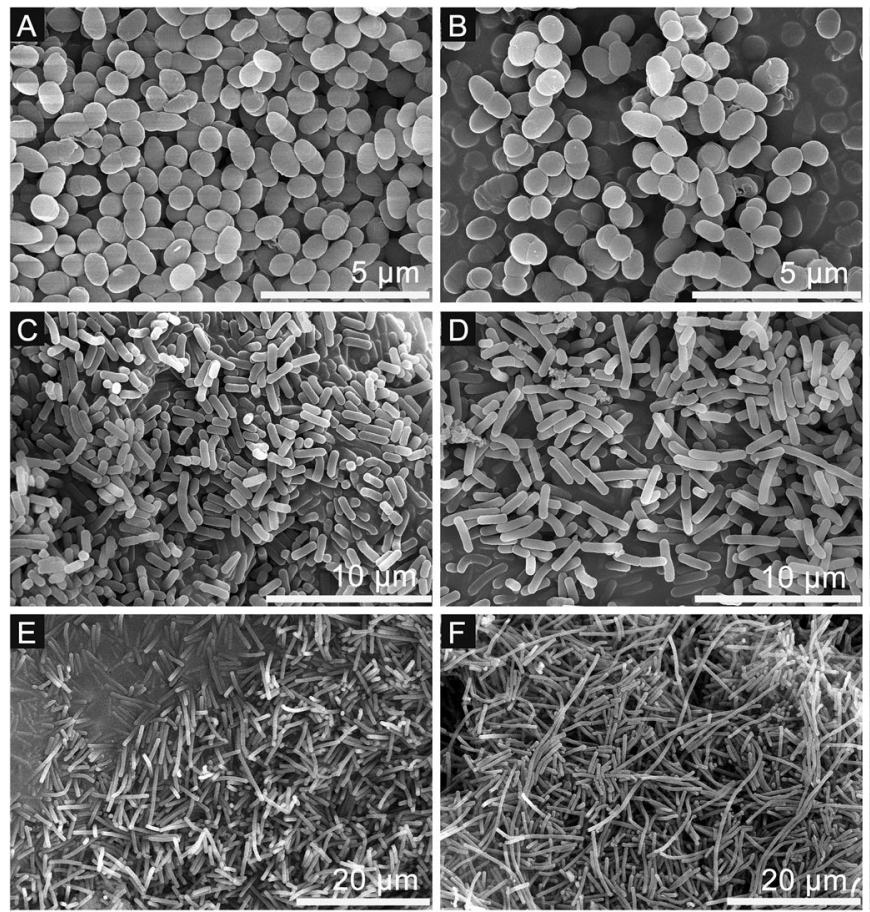

Fig. 4 The morphology of three LAB strains grown at the standard and elevated temperatures. (A, a) Lactococcus lactis ssp. cremoris grown at $30{ }^{\circ} \mathrm{C},(\mathrm{B}, \mathrm{b})$ Lactococcus lactis ssp. cremoris grown at $33{ }^{\circ} \mathrm{C},(\mathrm{C}, \mathrm{c})$ Lactobacillus rhamnosus $\mathrm{GG}$ grown at $37{ }^{\circ} \mathrm{C},(\mathrm{D}$, d) Lactobacillus

\section{Heat Treatment of LAB Strains Grown at Different Temperatures}

Heat treatment experiments were performed at $60{ }^{\circ} \mathrm{C}$ to evaluate the thermotolerance of the three strains (Fig. 5). As expected, L. cremoris cultured at $33^{\circ} \mathrm{C}$ in general showed better survival than that at $30{ }^{\circ} \mathrm{C}$ throughout the heat treatment for $14 \mathrm{~min}$ (Fig. 5a). The two survival curves exhibited large gaps at 4,10 , and $12 \mathrm{~min}$, where the survival ratio was increased by $0.7-1.5 \log$ with the increase in growth temperature. The survival curve of heat-adapted cells demonstrated a typical tailing effect after $8 \mathrm{~min}$ of heat treatment, indicating that a small portion of L. cremoris population $(<0.1 \%)$ had acquired excellent thermotolerance. Similarly, when the growth temperature of LGG was increased by $5{ }^{\circ} \mathrm{C}$, the survival of cells after heat treatment for $6 \mathrm{~min}$ was increased by around $0.3 \mathrm{log}$ (from around $12.5 \%$ to $25 \%, p<0.05$, Fig. $5 b$ ). Though the viable cell count in the fresh LGG culture at $42{ }^{\circ} \mathrm{C}$ was lower than that at $37^{\circ} \mathrm{C}$, the residual viability of the two cultures after heat treatment reached a similar level around $4 \times 10^{8}$ to 5 $\times 10^{8} \mathrm{cfu} / \mathrm{mL}(8.5-8.7 \log \mathrm{cfu} / \mathrm{mL})$, demonstrating the enhanced thermotolerance of LGG when cultured at $42{ }^{\circ} \mathrm{C}$.

The L. acidophilus culture at $42{ }^{\circ} \mathrm{C}$ showed a significant decrease in cell viability between 12 and $24 \mathrm{~h}$ of incubation, from around $1.5 \times 10^{8} \mathrm{cfu} / \mathrm{mL}$ to lower than $10^{7} \mathrm{cfu} / \mathrm{mL}(8.2$ compared to $6.8 \log \mathrm{cfu} / \mathrm{mL}$; Fig. $5 \mathrm{c}$ ), indicating that the culture entered death phase. After heating at $60^{\circ} \mathrm{C}$ for $4 \mathrm{~min}$, cells
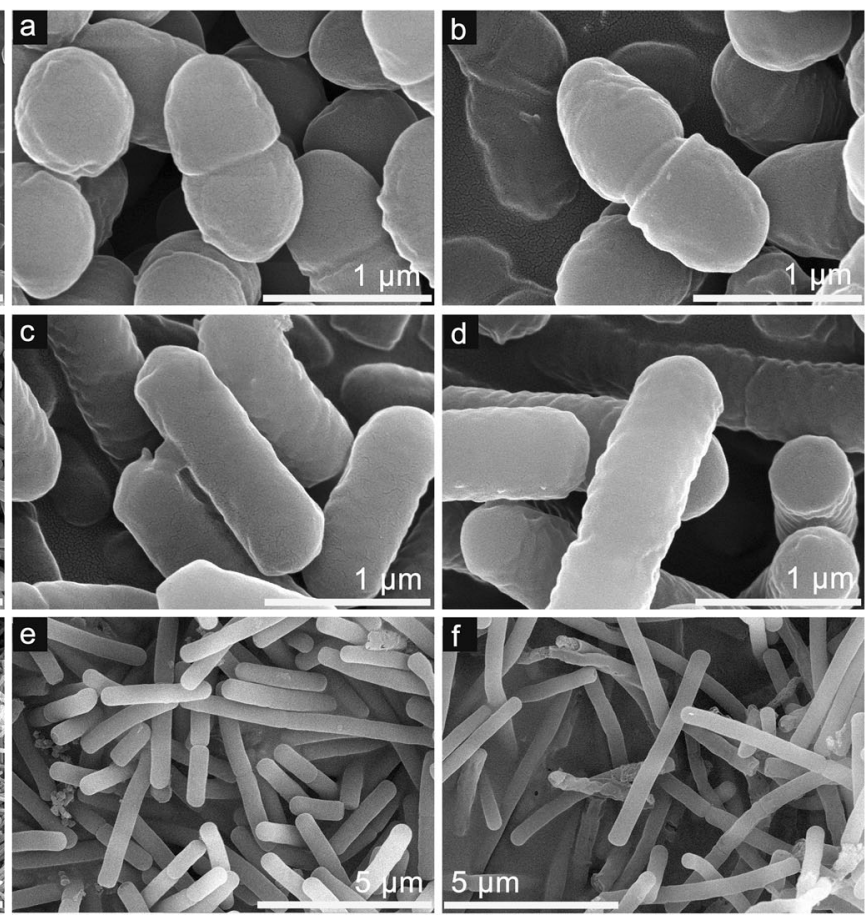

rhamnosus GG grown at $42{ }^{\circ} \mathrm{C}$, (E, e) Lactobacillus acidophilus NCFM grown at $37^{\circ} \mathrm{C}$, and (F, f) Lactobacillus acidophilus NCFM grown at $42{ }^{\circ} \mathrm{C}$ 


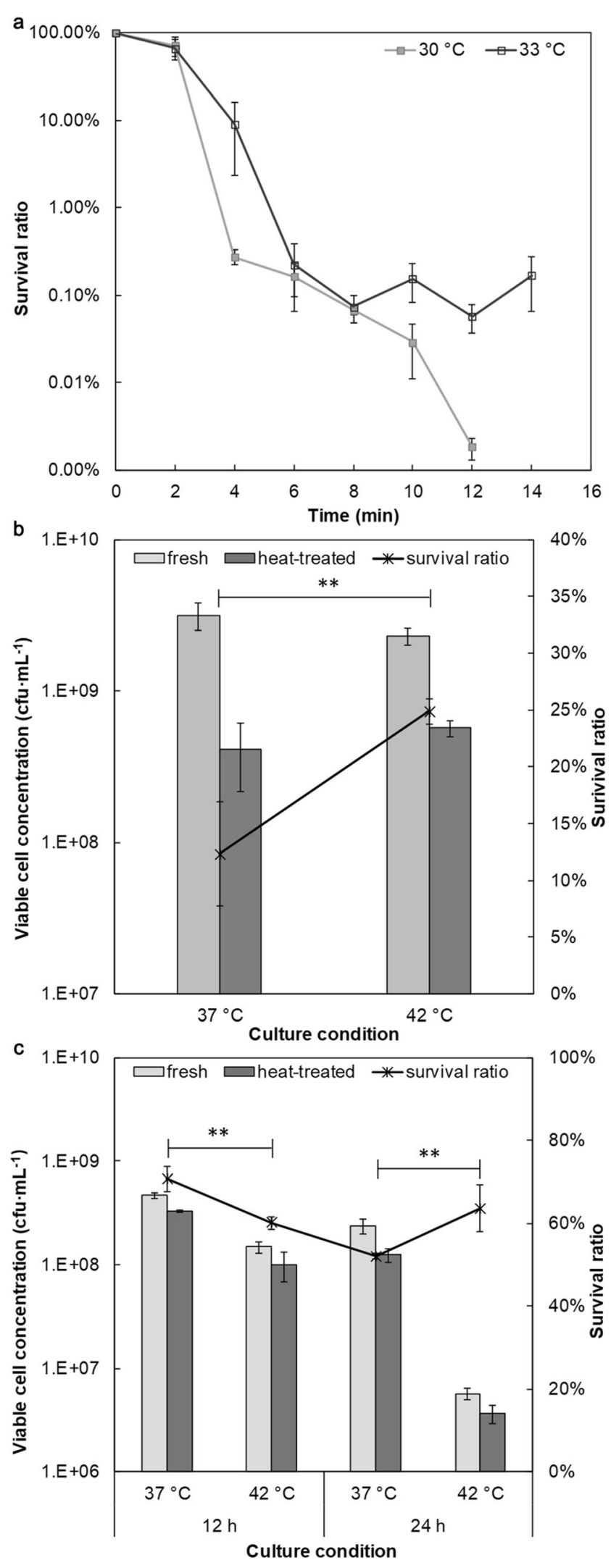

Fig. 5 Heat treatment of LAB cultures at $60^{\circ} \mathrm{C}$. a The inactivation curves of Lactococcus lactis ssp. cremoris grown at 30 and $33{ }^{\circ} \mathrm{C}$ during heat treatment for $14 \mathrm{~min}$. b The viable cell count and survival ratio of Lactobacillus rhamnosus GG grown at 37 and $42{ }^{\circ} \mathrm{C}$ after heat treatment for $6 \mathrm{~min}$. c The viable cell count and survival ratio of Lactobacillus acidophilus NCFM after heat treatment for $4 \mathrm{~min}$, with cells grown at 37 and $42{ }^{\circ} \mathrm{C}$ for either 12 or $24 \mathrm{~h} . * *$ indicate that the two survival ratios are significantly different $(p<0.05)$

grown at $42{ }^{\circ} \mathrm{C}$ for $12 \mathrm{~h}$ demonstrated lower survival than the control culture with the same incubation period $(60.1 \%$ and $70.8 \%$, respectively; $p<0.05$ ). By contrast, for the two cultures incubated for $24 \mathrm{~h}$, a higher survival ratio was observed for the heat-adapted culture $(63.7 \%$ and $52.1 \%$, respectively; $p$ $<0.05$ ), which was a similar trend to the results of $L$. cremoris and LGG. Nevertheless, because of the low viability, culturing L. acidophilus at $42{ }^{\circ} \mathrm{C}$ for $24 \mathrm{~h}$ was unsuitable for utilization in powder production. In the present study, an incubation time of $12 \mathrm{~h}$ was used to grow $L$. acidophilus at $42{ }^{\circ} \mathrm{C}$.

\section{Spray Drying of LAB Strains Grown at Different Temperatures}

Spray drying experiments of the six cultures were carried out with the same protectant ( $30 \mathrm{wt} \%$ reconstituted skim milk) under similar drying conditions. As such, LAB cells in each culture had experienced similar stresses during drying, and any difference in the survival ratio after spray drying could be considered the result of the different intrinsic tolerance of cells. In the preparation of feed containing LGG and $L$. acidophilus, cells cultured at different temperatures were mixed with the protectant at the same ratio of culture volume to protectant volume (1:10). The resulting feed prepared with the control cultures grown at $37^{\circ} \mathrm{C}$ showed higher viable cell counts than that with heat-adapted cultures grown at $42{ }^{\circ} \mathrm{C}$ (Fig. 6a), which was in line with the results in Fig. 2. The viable cell count in the feed containing control LGG, heatadapted LGG, control L. acidophilus, and heat-adapted $L$. acidophilus was $3.97 \times 10^{8}, 1.69 \times 10^{8}, 1.81 \times 10^{8}$, and $5.77 \times 10^{7} \mathrm{cfu} / \mathrm{g}(8.59,8.22,8.16$, and $7.60 \mathrm{log} \mathrm{cfu} / \mathrm{g})$, respectively. After spray drying, substantial viability loss was observed for all four cultures. The residual viability in spray dried powder was $8.67 \times 10^{7}$ and $5.03 \times 10^{7} \mathrm{cfu} / \mathrm{g}(7.90$ and $7.69 \mathrm{log} \mathrm{cfu} / \mathrm{g}$ ) for LGG cultures at 37 and $42{ }^{\circ} \mathrm{C}$, and $5.05 \times$ $10^{7}$ and $2.36 \times 10^{7} \mathrm{cfu} / \mathrm{g}(7.60$ and $7.22 \mathrm{log} \mathrm{cfu} / \mathrm{g}$ ) for $L$. acidophilus cultures at 37 and $42{ }^{\circ} \mathrm{C}$, respectively. In average, the heat-adapted lactobacilli strains tended to show higher survival ratio in spray-dried powders than the control cultures, respectively $42.3 \%$ and $28.6 \%$ for L. acidophilus, $30.9 \%$ and $21.0 \%$ for LGG (Fig. 6b). The difference was significant between the L. acidophilus cultures $(p<0.05)$ and relatively insignificant between the LGG cultures $(p=0.06)$. 
In the spray drying of $L$. cremoris, the heat-adapted culture grown at $33{ }^{\circ} \mathrm{C}$ was mixed with $30 \mathrm{wt} \%$ skim milk at a ratio of culture volume to protectant volume of 1:5, whereas for the control culture grown at $30{ }^{\circ} \mathrm{C}$, a 1:10 ratio was used. The results showed that the positive effect of the enhanced thermotolerance on the survival of spray-dried LAB cells was minimally affected by the different cell:protectant ratio. The survival ratio of the heat-adapted L. cremoris reached $52.4 \%$, notably higher than that of the control culture $(31.4 \%, p<$ 0.05 ; Fig. $6 \mathrm{~b}$ ). The increased cell:protectant ratio resulted in a relatively high concentration of viable cells in the feed, reaching $3.68 \times 10^{8} \mathrm{cfu} / \mathrm{g}(8.46 \mathrm{log} \mathrm{cfu} / \mathrm{g}$; Fig. 6a). The residual viability of $L$. cremoris in spray-dried powder was correspondingly increased, reaching $1.68 \times 10^{8} \mathrm{cfu} / \mathrm{g}(8.17 \mathrm{log} \mathrm{cfu} /$ g; Fig. 6a). The increased cell density is an advantage in industrial powder production, because it allows bacterial population per unit mass of final product to be maintained at a comparatively high level, even after the powder is mixed with other excipient material.

The moisture content of the six types of LAB powders was similar, ranging between 6.8 and $8.6 \%$. The powders also showed similar particle size around $130 \mu \mathrm{m}$ and similar particle morphology of distorted spherical shape, as shown by the images of microparticles encapsulating $L$. cremoris, LGG and L. acidophilus cultured at elevated growth temperatures (Fig. $7 \mathrm{~A}-\mathrm{C}$ ). The morphology of bacterial cells embedded in the skim milk matrix is correspondingly shown in Fig. 7a-c. At the broken surface of microparticles, LAB cells can be distinguished from milk solids by their characteristic cellular shape. The chain arrangement was observed for L. cremoris cells, as shown with a closed red arrow in Fig. 7a. Notably, some pits with clear cellular shape were found at the cross section of the microparticles (refer to open blue arrows in Fig. 7a, b). The pits indicated that LAB cells were once present, which might be lost under the high vacuum during sputter-coating and SEM observation.

\section{Stability of Spray-Dried LAB Cells During Storage}

The changes of LAB viability in spray-dried powders were monitored during storage at $4{ }^{\circ} \mathrm{C}$ for 110 days. The bacterial population in the six types of LAB powders after spray drying was different (Fig. 8a). To make more effective comparison between the changing trends of LAB viability during storage, the viable cell count measured at different storage periods was normalized with the value of fresh LAB powder cell count (Fig. 8b). After 110 days, the overall decrease in the viability of LGG and L. acidophilus was around $1 \log$, whereas for $L$. cremoris, a decrease of up to 2.0-2.2 log was observed. The rapid loss of LAB viability occurred during the first 2 weeks of storage, and then the curves nearly leveled off till the end of storage test (Fig. 8b). L. cremoris and LGG cultures grown at the elevated temperatures demonstrated higher degree of inactivation than the control cultures at the standard temperatures. After 7 days of storage, the viability of the heat-adapted cultures was decreased to a lower level than that of the control cultures, and the reduction in viability was 1.23 and $0.90 \mathrm{log}$ for L. cremoris, and 1.03 and $0.87 \log$ for LGG, respectively. The gap was maintained till the end of the storage trial. By contrast, the control and heat-adapted L. acidophilus showed similar trends of viability loss during 110 days.

All six types of LAB powders retained viable cell counts close to or higher than $10^{6} \mathrm{cfu} / \mathrm{g}$ after storage for 110 days
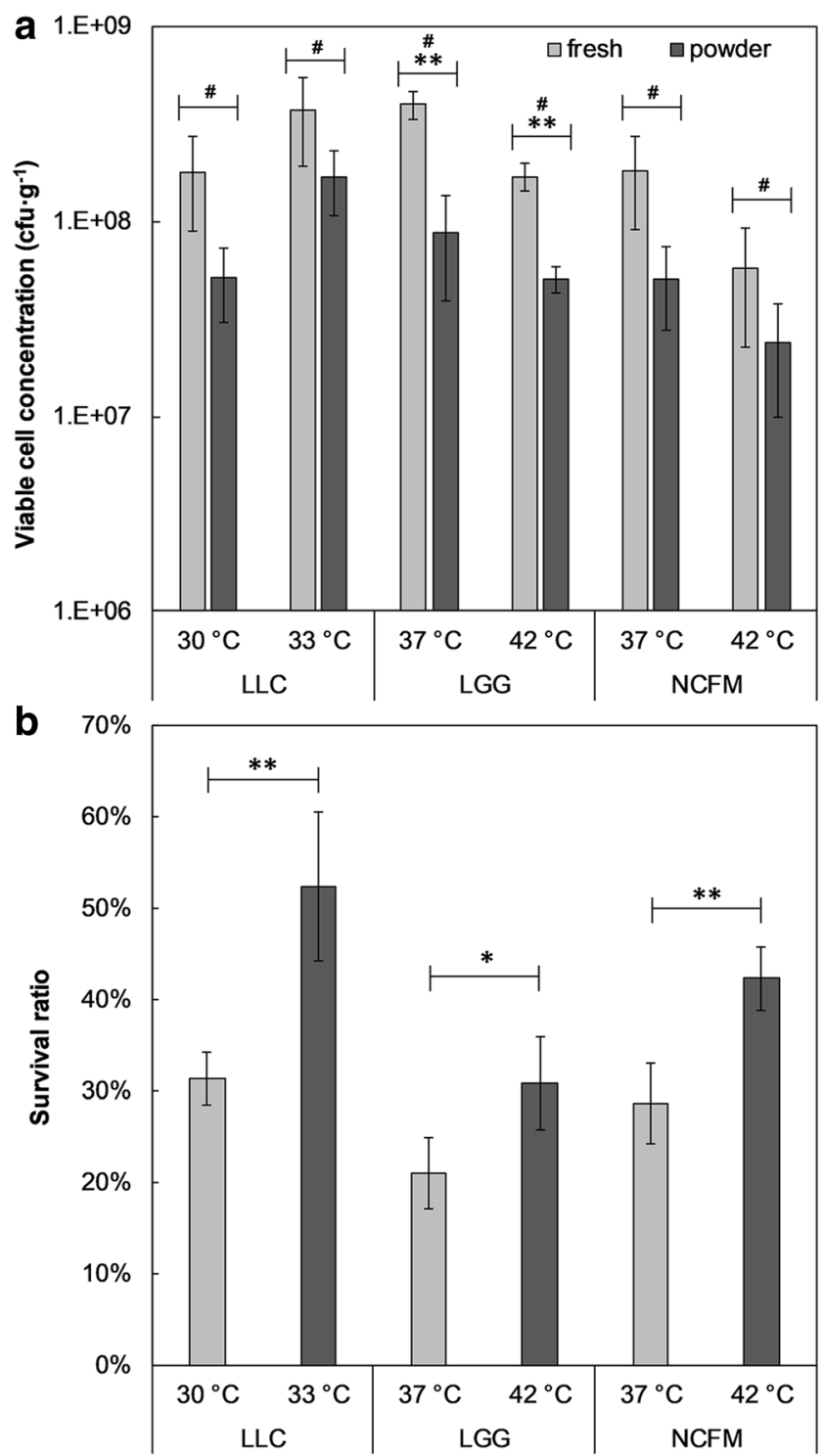

Fig. 6 Spray drying of three LAB strains grown at the standard and elevated temperatures, using $30 \mathrm{wt} \%$ reconstituted skim milk as protectant. a The viable cell counts in the feed and in freshly dried powder. b The survival ratio of the six cultures. LLC Lactococcus lactis ssp. cremoris, LGG Lactobacillus rhamnosus GG, NCFM Lactobacillus acidophilus NCFM. $*$ and $* *$ indicate that the significance of difference between the two values is $p<0.1$ and $p<0.05$, respectively. \# in panel a indicates that the two viable cell counts are significantly different when analyzed in $\log \mathrm{cfu} \cdot \mathrm{g}^{-1}$ form $(p<0.05)$ 
(Fig. 8a). The highest viability of $5.3 \times 10^{6} \mathrm{cfu} / \mathrm{g}(6.72 \mathrm{log} \mathrm{cfu} /$ g) was observed with $L G G$ cultured at $37^{\circ} \mathrm{C}$, followed by $L$. acidophilus cultured at $37^{\circ} \mathrm{C}$ with a residual viability of $3.5 \times$ $10^{6} \mathrm{cfu} / \mathrm{g}(6.52 \log \mathrm{cfu} / \mathrm{g})$. L. cremoris cultured at $30^{\circ} \mathrm{C}$ showed the lowest viability of $9.6 \times 10^{5} \mathrm{cfu} / \mathrm{g}(5.98 \mathrm{log} \mathrm{cfu} /$ $\mathrm{g}$ ) among the six types of powders, which was attributed both to the substantial inactivation during storage and to the low viable cell count in freshly spray-dried powder at day 0 (Fig. $8 a)$.

\section{Discussion}

Owing to the biological properties of LAB as living microorganisms, the microencapsulation of LAB cells via spray drying demonstrates several unique features that are different from the processing of other bio-active substances. First of all, by dehydrating LAB cells, it is expected to inhibit their metabolic activities, so as to extend the term of preservation of cell viability (Fu and Chen 2011). Second, the response of $\mathrm{LAB}$ cells toward environmental stresses and protectants needs to be taken into account. Different genus, species, and strains may exhibit varying degrees of responses (Iaconelli et al. 2015; Salar-Behzadi et al. 2013) as a result of differences in gene expression, level of stress proteins, and metabolic pathways. A common criterion to examine the survival of LAB cells after spray drying is by measuring cell viability, that is, the capability of cells to multiply in rich medium (Ali et al. 2019). The result possibly includes a proportion of injured cells, which could repair the injuries and continue to multiply (Golowczyc et al. 2011; Liu et al. 2015). Furthermore, the potential beneficial effect that may be conferred by LAB cells without reproduction capability, including both inactivated cells and viable-but-nonculturable cells, remains elusive (Generoso et al. 2011; Zhang et al. 2005).

Since bacterial cells could activate stress response systems under stressful conditions, a viable approach to increase $\mathrm{LAB}$ survival after spray drying is to enhance the intrinsic stress tolerance of cells (Desmond et al. 2001; Gaucher et al. 2020; Huang et al. 2016b). This approach is in addition to common strategies used to improve the quality of powders that encapsulate bio-active substances, such as the optimization of microencapsulation process (Zhao et al. 2018; Zhao et al. 2019) and the use of appropriate protectants (Agudelo et al. 2017; Bustamante et al. 2017). In this study, the enhanced thermotolerance of $L$. cremoris and LGG grown at the increased temperatures (Fig. 5a, b) was in agreement with the findings in previous reports (Cebrián et al. 2019; Dijkstra et al. 2014). By contrast, L. acidophilus grown at $42{ }^{\circ} \mathrm{C}$ showed substantially shortened stationary phase (Fig. 5 c), and its thermotolerance was largely influenced by the growth phase. At the high temperature, certain essential cellular activities might be compromised to an overly high degree that cannot be countered by cellular response system, leading to variations in cell survival after heat treatment (Wang et al. 2020).

The increase in growth temperature by $3{ }^{\circ} \mathrm{C}$ for L. cremoris and by $5{ }^{\circ} \mathrm{C}$ for lactobacilli exceeded the optimum temperature for culturing the individual strain. The resulting cultures
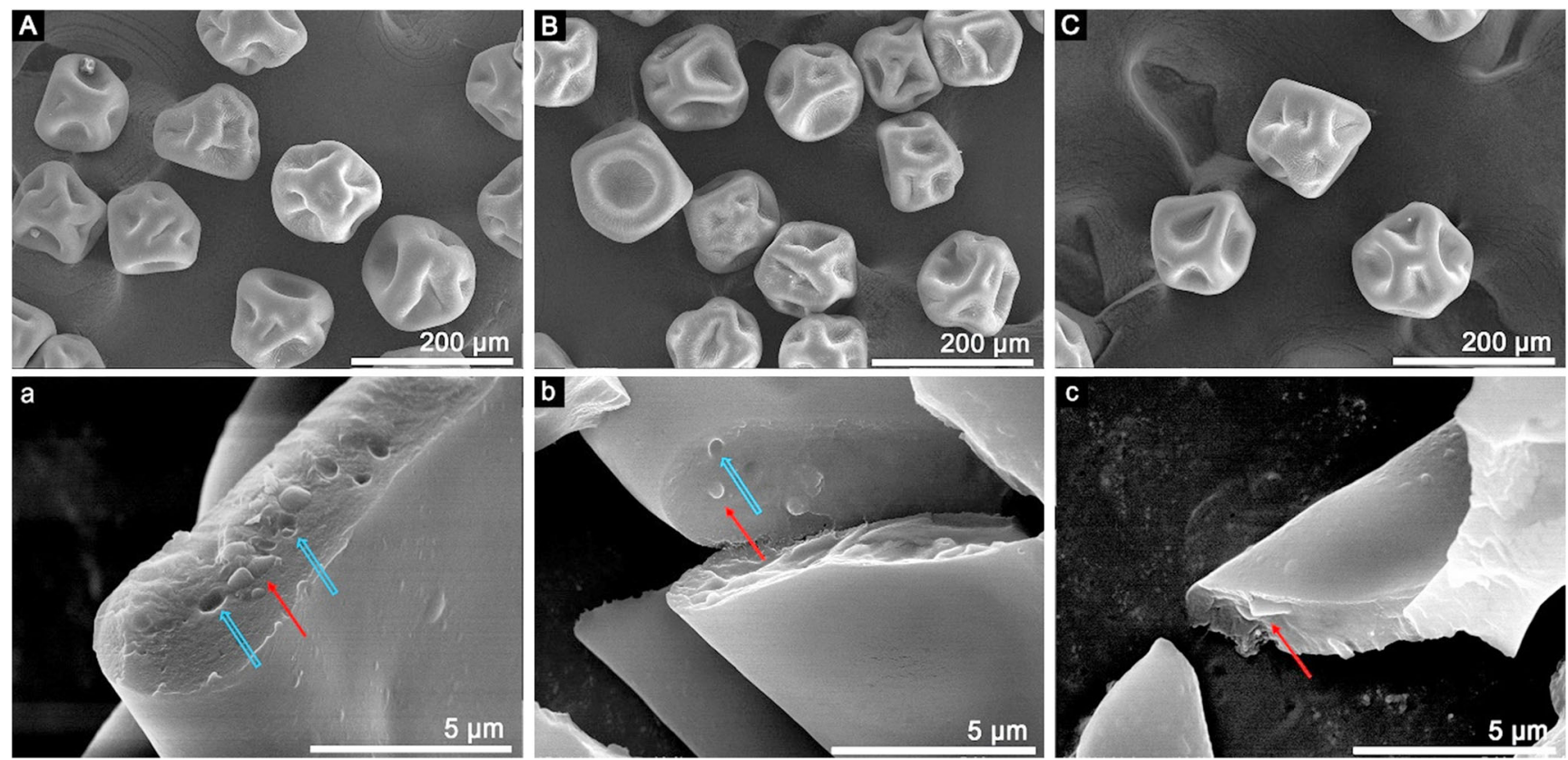

Fig. 7 Particle morphology of powders encapsulating LAB cells cultured at elevated growth temperatures, using reconstituted skim milk as protectant. (A) Lactococcus lactis ssp. cremoris grown at $33{ }^{\circ} \mathrm{C}$, (B) Lactobacillus rhamnosus GG grown at $42{ }^{\circ} \mathrm{C}$, and (C) Lactobacillus

acidophilus NCFM grown at $42{ }^{\circ} \mathrm{C}$, respectively. (a-c) Show the morphology of corresponding LAB cells encapsulated in the skim milk matrix. Solid red arrows indicate the encapsulated LAB cells, whereas open blue arrows indicate pits with cellular shape 
tended to show lower bacterial population at the stationary phase than the control cultures (Fig. 2), indicating the negative effect of the high temperature on bacterial growth. Nevertheless, the high temperature could promote the rate of enzymatic reactions as commonly observed for most chemical reactions (Madigan and Martinko 2006). The increased rate of enzymatic reactions might compensate for the low amount of viable cells, resulting in the similar metabolic activity of the heat-adapted cultures to the controls (Fig. 3). Since enzymatic reactions play a key role in the majority of cellular activities such as energy metabolism, DNA replication, and protein synthesis (Madigan and Martinko 2006), the high reaction rate could be associated with the acceleration of cellular activities. One of the indications was the early occurrence of the stationary growth phase for L. acidophilus grown at $42{ }^{\circ} \mathrm{C}$. In addition, the rapid division of cells could be partly reflected by the elongated cellular morphology of the lactobacilli strains (Fig. 4D, d, F, f).

The increased survival of heat-adapted $L$. cremoris and $L$. acidophilus after spray drying was an expected trend, because heat stress in addition to dehydration stress was considered a main factor responsible for the inactivation of LAB cells during spray drying (Ghandi et al. 2012; Perdana et al. 2013). Though the difference between the control and heat-adapted LGG cultures remained insignificant with triplicate experiments ( $p=0.06, n=3$ ), it was possible that the difference may become significant with the increase in sample size. The inlet and outlet temperatures of the spray drying processes used in the current study were controlled at low levels (100 and $58{ }^{\circ} \mathrm{C}$, respectively). Nevertheless, the temperature history experienced by individual droplets during drying might enter high temperature range for a short time (Rogers et al. 2012), constituting heat challenge for LAB cells. A high temperature environment above the maximum growth temperature of bacteria favored the survival of cells with enhanced thermotolerance. Previous studies showed that spray dried LAB cells exhibited higher degree of damages on lipid structure and secondary protein structures (Hlaing et al. 2017), as well as on certain functionalities such as the hydrophobicity of cellular surface (Iaconelli et al. 2015), than cells dehydrated by freeze drying, which was free of heat stress. In future studies, the temperature of spray drying needs to be further lowered to minimize the detrimental effect of heat.

It is well known that prokaryotic cells could activate heat shock proteins toward heat stress (De Angelis and Gobbetti 2004; Papadimitriou et al. 2016; van de Guchte et al. 2002). Although the specific cellular response mechanism varies among species and strains, the conserved chaperones such as GroES, GroEL, DnaK, and DnaJ families are often identified in LAB cells after heat shock (De Angelis and Gobbetti 2004; Sanders et al. 1999). At an increased environmental temperature, not only the expression of stress proteins is increased in LAB cells, but the capacity of chaperones binding to unfolded polypeptides also demonstrates substantial improvement (Sherman and Goldberg 1993). As such, culturing LAB cells at an elevated growth temperature might be able to maintain chaperone proteins active, leading to the improved cell thermotolerance observed in the current study. In addition, our results showed that such a strategy could effectively increase the survival of spray-dried LAB cells, which was reported for the first time.

The decreased stability shown by the heat-adapted $L$. cremoris and LGG during storage at $4{ }^{\circ} \mathrm{C}$ was an unfavorable attribute in industrial production. The compromised stability might be ascribed to two reasons. First, LAB cells grown
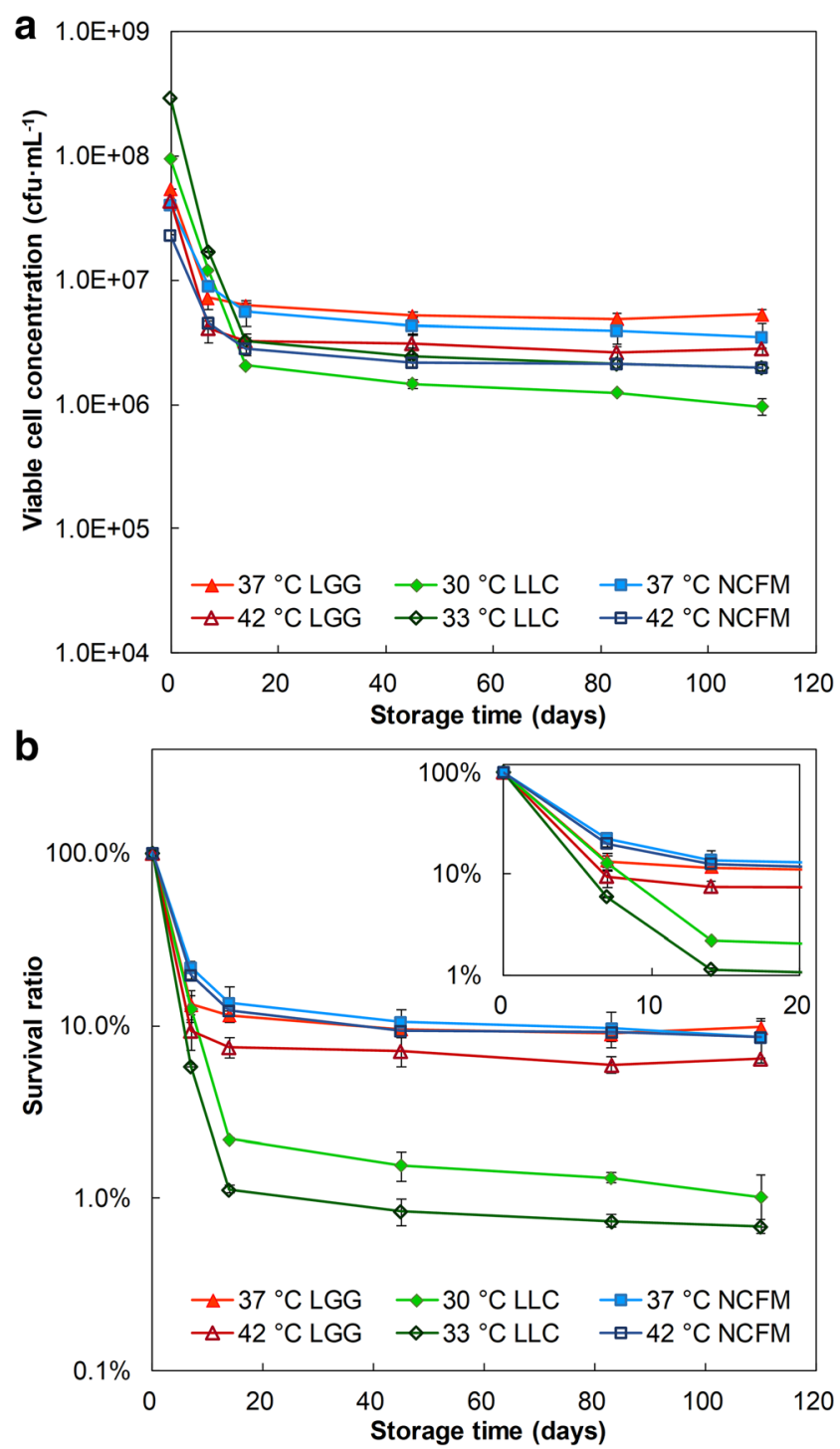

Fig. 8 Changes in cell viability in six types of LAB powders encapsulating three LAB strains grown at the standard and elevated temperatures, during storage at $4{ }^{\circ} \mathrm{C}$. a Viable cell count. b Survival ratio. The inset in panel $\mathbf{b}$ compares the trends of viability decrease during storage for 20 days. $L L C$ Lactococcus lactis ssp. cremoris, $L G G$ Lactobacillus rhamnosus GG, NCFM Lactobacillus acidophilus NCFM 
under the high temperature naturally tend to be instable. The instability, which could be linked to the rapid division, is in line with the low bacterial population at the stationary growth phase (Fig. 2). Second, freshly spray-dried LAB powder may contain a proportion of cells bearing sublethal injuries (Ananta et al. 2005). Cebrián et al. (2019) reported that bacterial culture grown at an elevated temperature tends to contain a larger proportion of sublethally damaged cells than the culture grown at the standard condition. When heat-adapted cultures were spray-dried and immediately analyzed for cell survival, the injured bacterial population might be able to repair the injuries and continue to multiply in the rich growth medium, particularly with the highly active chaperon proteins. As a result, high survival ratios of $\mathrm{LAB}$ were observed for the heat-adapted cultures after spray drying (Fig. 6b). During storage of spray-dried powders, cellular activities in the milk matrix were decreased to a low level, and the injured cells might gradually lose the capability to reproduce. As such, the higher proportion of injured cells in the heat-adapted cultures led to a higher degree of inactivation than the control cultures after the first week of storage, and the difference in viability was maintained during the following storage period (Fig. 8b).

Besides the cultivation of LAB at elevated temperature, previous studies have reported other cultivation approaches that are capable of improving the thermotolerance of cells, such as culturing cells in concentrated sweet whey of 20-30 wt\% total solids (Huang et al. 2016b), or in growth medium supplemented with $\mathrm{Ca}^{2+}$ (Wang et al. 2020). Probiotic strains cultured in concentrated sweet whey demonstrated excellent survival after spray drying and good stability during storage (Huang et al. 2016a; Huang et al. 2017), indicating that balanced thermotolerance and storage stability may be achieved by optimizing cultivation and spray drying conditions. As shown in the current study, the enhanced thermotolerance and increased cell survival after spray drying may not directly correlate with an improved storage stability of spray-dried LAB, suggesting that the cellular response of $\mathrm{LAB}$ depends on the specific culturing conditions and protectant composition, and should be carefully controlled to maximize the retention of cell viability during processing and storage.

\section{Conclusions}

This study evaluated the potential of culturing LAB strains at elevated temperatures for increasing the survival of bacterial cells after spray drying. Increasing the growth temperature of L. cremoris, LGG, and L. acidophilus by $3-5{ }^{\circ} \mathrm{C}$ led to a general improvement of the thermotolerance of cells, and also impacted on the biological properties of strains, including decreased bacterial population at the stationary growth phase, increased metabolic activity of individual cells, and the elongation of lactobacilli cells. The survival ratios of $L$. cremoris and $L$. acidophilus after spray drying were significantly increased from 31.4 to $52.4 \%$ and from 28.6 to $42.3 \%$, respectively; whereas heat-adapted LGG also showed increased survival from 21.0 to $30.9 \%$, which was relatively insignificant. Spray-dried powders prepared with heatadapted L. cremoris and LGG showed a higher degree of viability loss by $1.03-1.23 \mathrm{log}$ during the first week of storage, which might be related to the proportion of injured cells in the powders. The findings demonstrated the crucial effect of cellular response on $\mathrm{LAB}$ viability retention during spray drying and storage. While culturing LAB strains at elevated temperatures proved to be useful in increasing the survival of cells toward heat stress, the resulting cellular response required further optimization in future studies, to yield robust cells with high activity and stability. Understanding the cellular response of LAB toward different cultivation and processing conditions facilitates a rational process design for producing active $\mathrm{LAB}$ powders via spray drying.

Acknowledgments This work was supported by the Natural Science Foundation of China (grant numbers 31601513), Jiangsu Agriculture Science and Technology Innovation Fund (JASTIF, grant number CX(20)3048), the National Key Research and Development Program of China (project number 2016YFE0101200, International S\&T Cooperation Program, ISTCP), and the Priority Academic Program Development (PAPD) of Jiangsu Higher Education Institutions. The first author thanks Miss Yan Wang for fruitful discussion on the cultivation of L. cremoris.

Nomenclature cfu, Colony-forming unit; INT, Iodonitrotetrazolium chloride; LAB, Lactic acid bacteria; LGG, Lactobacillus rhamnosus GG; LLC, Lactococcus lactis subsp. cremoris ATCC 19257; M17 broth, Broth used to culture lactococci; MRS broth, de Man, Rogosa and Sharpe broth used to culture lactobacilli; $N_{0}$, The viability of lactic acid bacteria in the feed of spray drying (cfu/g dry solids mass); $N_{p}$, The viability of lactic acid bacteria in spray dried powder (cfu/g dry solids mass); NCFM, Lactobacillus acidophilus NCFM; PBG, Phosphate buffer containing glucose; RSM, Reconstituted skim milk

\section{References}

Agudelo, J., Cano, A., González-Martínez, C., \& Chiralt, A. (2017). Disaccharide incorporation to improve survival during storage of spray dried Lactobacillus rhamnosus in whey protein-maltodextrin carriers. Journal of Functional Foods, 37, 416-423.

Ali, M. A., Zhang, Z. W., Li, H. F., Zhang, Y. S., Fu, S. Q., Zhang, W., Man, C. X., \& Jiang, Y. J. (2019). A culture-independent method for enumeration of viable load of Lactobacillus acidophilus NCFM by using real-time PCR. International Journal of Food Engineering, 15(10), 20190079.

Ananta, E., Volkert, M., \& Knorr, D. (2005). Cellular injuries and storage stability of spray-dried Lactobacillus rhamnosus GG. International Dairy Journal, 15(4), 399-409.

Arslan-Tontul, S., \& Erbas, M. (2017). Single and double layered microencapsulation of probiotics by spray drying and spray chilling. $L W T$ - Food Science and Technology, 81, 160-169. 
Bansal, T., \& Garg, S. (2008). Probiotics: from functional foods to pharmaceutical products. Current Pharmaceutical Biotechnology, 9(4), 267-287.

Bustamante, M., Oomah, B. D., Rubilar, M., \& Shene, C. (2017). Effective Lactobacillus plantarum and Bifidobacterium infantis encapsulation with chia seed (Salvia hispanica L.) and flaxseed (Linum usitatissimum L.) mucilage and soluble protein by spray drying. Food Chemistry, 216, 97-105.

Cebrián, G., Condón, S., \& Mañas, P. (2019). Heat resistance, membrane fluidity and sublethal damage in Staphylococcus aureus cells grown at different temperatures. International Journal of Food Microbiology, 289, 49-56.

De Angelis, M., \& Gobbetti, M. (2004). Environmental stress response in Lactobacillus: a review. Proteomics, 4(1), 106-122.

Desmond, C., Stanton, C., Fitzgerald, G. F., Collins, K., \& Ross, R. P. (2001). Environmental adaptation of probiotic lactobacilli towards improvement of performance during spray drying. International Dairy Journal, 11(10), 801-808.

Dijkstra, A. R., Alkema, W., Starrenburg, M. J. C., Hugenholtz, J., van Hijum, S. A., \& Bron, P. A. (2014). Fermentation-induced variation in heat and oxidative stress phenotypes of Lactococcus lactis MG1363 reveals transcriptome signatures for robustness. Microbial Cell Factories, 13, 148.

Dimitrellou, D., Kandylis, P., Petrović, T., Dimitrijević-Branković, S., Lević, S., Nedović, V., \& Kourkoutas, Y. (2016). Survival of spray dried microencapsulated Lactobacillus casei ATCC 393 in simulated gastrointestinal conditions and fermented milk. LWT - Food Science and Technology, 71, 169-174.

Forster, S. C., \& Lawley, T. D. (2015). Systematic discovery of probiotics. Nature Biotechnology, 33(1), 47-49.

Fritzen-Freire, C. B., Prudêncio, E. S., Pinto, S. S., Muñoz, I. B., \& Amboni, R. D. M. C. (2013). Effect of microencapsulation on survival of Bifidobacterium BB-12 exposed to simulated gastrointestinal conditions and heat treatments. LWT - Food Science and Technology, 50(1), 39-44.

$\mathrm{Fu}$, N., \& Chen, X. D. (2011). Towards a maximal cell survival in convective thermal drying processes. Food Research International, 44(5), 1127-1149.

Fu, N., Huang, S., Xiao, J., \& Chen, X. D. (2018). Chapter sixproducing powders containing active dry probiotics with the aid of spray drying. In F. Toldrá (Ed.), Advances in Food and Nutrition Research (Vol. 85, pp. 211-262): Academic Press.

Fu, N., You, Y.-J., Quek, S. Y., Wu, W. D., \& Chen, X. D. (2020). Interplaying effects of wall and core materials on the property and functionality of microparticles for co-encapsulation of vitamin $\mathrm{E}$ with coenzyme $\mathrm{Q}_{10}$. Food and Bioprocess Technology, 13(4), 705-721.

Fu, N., Zhou, Z., Jones, T. B., Tan, T. T. Y., Wu, W. D., Lin, S. X. Q., Chen, X. D., \& Chan, P. P. Y. (2011). Production of monodisperse epigallocatechin gallate (EGCG) microparticles by spray drying for high antioxidant activity retention. International Journal of Pharmaceutics, 413(1-2), 155-166.

Gaucher, F., Rabah, H., Kponouglo, K., Bonnassie, S., Pottier, S., Dolivet, A., Marchand, P., Jeantet, R., Blanc, P., \& Jan, G. (2020). Intracellular osmoprotectant concentrations determine Propionibacterium freudenreichii survival during drying. Applied Microbiology and Biotechnology, 104(7), 3145-3156.

Generoso, S. V., Viana, M. L., Santos, R. G., Arantes, R. M. E., Martins, F. S., Nicoli, J. R., Machado, J. A. N., Correia, M. I. T. D., \& Cardoso, V. N. (2011). Protection against increased intestinal permeability and bacterial translocation induced by intestinal obstruction in mice treated with viable and heat-killed Saccharomyces boulardii. European Journal of Nutrition, 50(4), 261-269.

Ghandi, A., Powell, I., Chen, X. D., \& Adhikari, B. (2012). Drying kinetics and survival studies of dairy fermentation bacteria in convective air drying environment using single droplet drying. Journal of Food Engineering, 110(3), 405-417.

Golowczyc, M. A., Silva, J., Teixeira, P., De Antoni, G. L., \& Abraham, A. G. (2011). Celluar injuries of spray-dried Lactobacillus spp. isolated from kefir and their impact on probiotic properties. International Journal of Food Microbiology, 144(3), 556-560.

Gong, P., Sun, J., Lin, K., Di, W., Zhang, L., \& Han, X. (2019). Changes process in the cellular structures and constituents of Lactobacillus bulgaricus sp1.1 during spray drying. LWT - Food Science and Technology, 102, 30-36.

Gul, O., \& Atalar, I. (2019). Different stress tolerance of spray and freeze dried Lactobacillus casei Shirota microcapsules with different encapsulating agents. Food Science and Biotechnology, 28(3), 807816.

Hlaing, M. M., Wood, B. R., McNaughton, D., Ying, D., Dumsday, G., \& Augustin, M. A. (2017). Effect of drying methods on protein and DNA conformation changes in Lactobacillus rhamnosus GG cells by Fourier transform infrared spectroscopy. Journal of Agricultural and Food Chemistry, 65(8), 1724-1731.

Huang, S., Cauty, C., Dolivet, A., Le Loir, Y., Chen, X. D., Schuck, P., Jan, G., \& Jeantet, R. (2016a). Double use of highly concentrated sweet whey to improve the biomass production and viability of spray-dried probiotic bacteria. Journal of Functional Foods, 23, 453-463.

Huang, S., Méjean, S., Rabah, H., Dolivet, A., Le Loir, Y., Chen, X. D., Jan, G., Jeantet, R., \& Schuck, P. (2017). Double use of concentrated sweet whey for growth and spray drying of probiotics: Towards maximal viability in pilot scale spray dryer. Journal of Food Engineering, 196, 11-17.

Huang, S., Rabah, H., Jardin, J., Briard-Bion, V., Parayre, S., Maillard, M. B., Le Loir, Y., Chen, X. D., Schuck, P., Jeantet, R., \& Jan, G. (2016b). Hyperconcentrated sweet whey, a new culture medium that enhances Propionibacterium freudenreichii stress tolerance. Applied and Environmental Microbiology, 82(15), 4641-4651.

Iaconelli, C., Lemetais, G., Kechaou, N., Chain, F., Bermúdez-Humarán, L. G., Langella, P., Gervais, P., \& Beney, L. (2015). Drying process strongly affects probiotics viability and functionalities. Journal of Biotechnology, 214, 17-26.

Jin, Y., \& Chen, X. D. (2010). A fundamental model of particle deposition incorporated in CFD simulations of an industrial milk spray dryer. Drying Technology, 28(8), 960-971.

Kavitake, D., Kandasamy, S., Devi, P. B., \& Shetty, P. H. (2018). Recent developments on encapsulation of lactic acid bacteria as potential starter culture in fermented foods - a review. Food Bioscience, 21, $34-44$.

Leuenberger, P., Ganscha, S., Kahraman, A., Cappelletti, V., Boersema, P. J., von Mering, C., Claassen, M., \& Picotti, P. (2017). Cell-wide analysis of protein thermal unfolding reveals determinants of thermostability. Science, 355(6327), eaai7825.

Liu, B., Fu, N., Woo, M. W., \& Chen, X. D. (2018a). Heat stability of Lactobacillus rhamnosus $\mathrm{GG}$ and its cellular membrane during droplet drying and heat treatment. Food Research International, $112,56-65$.

Liu, H., Gong, J., Chabot, D., Miller, S. S., Cui, S. W., Ma, J., Zhong, F., \& Wang, Q. (2015). Protection of heat-sensitive probiotic bacteria during spray-drying by sodium caseinate stabilized fat particles. Food Hydrocolloids, 51, 459-467.

Liu, H., Gong, J., Chabot, D., Miller, S. S., Cui, S. W., Zhong, F., \& Wang, Q. (2018b). Improved survival of Lactobacillus zeae LB1 in a spray dried alginate-protein matrix. Food Hydrocolloids, 78, 100108.

Madigan, M. T., \& Martinko, J. M. (2006). Microbial growth. In M. T. Madigan \& J. M. Martinko (Eds.), Brock Biology of Microorganisms (11th ed., pp. 135-165). Upper Saddle River: Pearson Education, Inc.. 
Oliveira, É. R., Fernandes, R. V. B., Botrel, D. A., Carmo, E. L., Borges, S. V., \& Queiroz, F. (2018). Study of different wall matrix biopolymers on the properties of spray-dried pequi oil and on the stability of bioactive compounds. Food and Bioprocess Technology, 11(3), 660-679.

Papadimitriou, K., Alegría, Á., Bron, P. A., de Angelis, M., Gobbetti, M., Kleerebezem, M., Lemos, J. A., Linares, D. M., Ross, P., Stanton, C., Turroni, F., van Sinderen, D., Varmanen, P., Ventura, M., Zúñiga, M., Tsakalidou, E., \& Kok, J. (2016). Stress physiology of lactic acid bacteria. Microbiology and Molecular Biology Reviews, 80(3), 837-890.

Peighambardoust, S. H., Golshan Tafti, A., \& Hesari, J. (2011). Application of spray drying for preservation of lactic acid starter cultures: A review. Trends in Food Science \& Technology, 22(5), 215-224.

Perdana, J., Bereschenko, L., Fox, M. B., Kuperus, J. H., Kleerebezem, M., Boom, R. M., \& Schutyser, M. A. I. (2013). Dehydration and thermal inactivation of Lactobacillus plantarum WCFS1: Comparing single droplet drying to spray and freeze drying. Food Research International, 54(2), 1351-1359.

Rabaioli Rama, G., Kuhn, D., Beux, S., Jachetti Maciel, M., \& Volken de Souza, C. F. (2020). Cheese whey and ricotta whey for the growth and encapsulation of endogenous lactic acid bacteria. Food and Bioprocess Technology, 13(2), 308-322.

Rogers, S., Wu, W. D., Lin, S. X. Q., \& Chen, X. D. (2012). Particle shrinkage and morphology of milk powder made with a monodisperse spray dryer. Biochemical Engineering Journal, 62, 92-100.

Salar-Behzadi, S., Wu, S., Toegel, S., Hofrichter, M., Altenburger, I., Unger, F. M., Wirth, M., \& Viernstein, H. (2013). Impact of heat treatment and spray drying on cellular properties and culturability of Bifidobacterium bifidum BB-12. Food Research International, 54(1), 93-101.

Sanders, J. W., Venema, G., \& Kok, J. (1999). Environmental stress responses in Lactococcus lactis. FEMS Microbiology Reviews, 23(4), 483-501.

Schutyser, M. A. I., Perdana, J., \& Boom, R. M. (2012). Single droplet drying for optimal spray drying of enzymes and probiotics. Trends in Food Science \& Technology, 27(2), 73-82.

Settachaimongkon, S., van Valenberg, H. J., Winata, V., Wang, X., Nout, M. J., van Hooijdonk, T. C., Zwietering, M. H., \& Smid, E. J. (2015). Effect of sublethal preculturing on the survival of probiotics and metabolite formation in set-yoghurt. Food Microbiology, 49, 104-115.

Sherman, M. Y., \& Goldberg, A. L. (1993). Heat shock of Escherichia coli increases binding of dnaK (the hsp70 homolog) to polypeptides by promoting its phosphorylation. Proceedings of the National Academy of Sciences of the United States of America, 90(18), 8648-8652.

Silva, J., Carvalho, A. S., Pereira, H., Teixeira, P., \& Gibbs, P. A. (2004). Induction of stress tolerance in Lactobacillus delbrueckii ssp. bulgaricus by the addition of sucrose to the growth medium. Journal of Dairy Research, 71(1), 121-125.

Su, Y., Zheng, X., Zhao, Q., Fu, N., Xiong, H., Wu, W. D., \& Chen, X. D. (2019). Spray drying of Lactobacillus rhamnosus GG with calciumcontaining protectant for enhanced viability. Powder Technology, 358, 87-94.

Suo, X. S., Huang, S., Wang, J., Fu, N., Jeantet, R., \& Chen, X. D. (2021). Effect of culturing lactic acid bacteria with varying skim milk concentration on bacteria survival during heat treatment. Journal of Food Engineering, 294, 110396. https://doi.org/10.1016/j. jfoodeng.2020.110396.

Tian, Y., Fu, N., Wu, W. D., Zhu, D., Huang, J., Yun, S., \& Chen, X. D. (2014). Effects of co-spray drying of surfactants with high solids milk on milk powder wettability. Food and Bioprocess Technology, 7(11), 3121-3135.

Tymczyszyn, E. E., Gomez-Zavaglia, A., \& Disalvo, E. A. (2007). Effect of sugars and growth media on the dehydration of Lactobacillus delbrueckii ssp. bulgaricus. Journal of Applied Microbiology, 102(3), 845-851.

Ulmer, H. M., Gänzle, M. G., \& Vogel, R. F. (2000). Effects of high pressure on survival and metabolic activity of Lactobacillus plantarum TMW1.460. Applied and Environmental Microbiology, 66(9), 3966-3973.

van de Guchte, M., Serror, P., Chervaux, C., Smokvina, T., Ehrlich, S. D., \& Maguin, E. (2002). Stress responses in lactic acid bacteria. Antonie Van Leeuwenhoek, 82(1-4), 187-216.

Vasiljevic, T., \& Shah, N. P. (2008). Probiotics-from Metchnikoff to bioactives. International Dairy Journal, 18(7), 714-728.

Wang, Y., Hao, F., Lu, W., Suo, X., Bellenger, E., Fu, N., Jeantet, R., \& Chen, X. D. (2020). Enhanced thermal stability of lactic acid bacteria during spray drying by intracellular accumulation of calcium. Journal of Food Engineering, 279, 109975.

Zhang, L., Li, N., Caicedo, R., \& Neu, J. (2005). Alive and dead Lactobacillus rhamnosus GG decrease tumor necrosis factor- $\alpha$-induced interleukin- 8 production in Caco- 2 cells. The Journal of Nutrition, 135(7), 1752-1756.

Zhao, M., Wang, Y., Huang, X., Gaenzle, M., Wu, Z., Nishinari, K., Yang, N., \& Fang, Y. (2018). Ambient storage of microencapsulated Lactobacillus plantarum ST-III by complex coacervation of typeA gelatin and gum arabic. Food \& Function, 9(2), 1000-1008.

Zhao, Y. P., Liu, S., Feng, Y. Q., \& Bilal, M. (2019). Development and optimization of attapulgite clay based microencapsulation for lactic acid bacteria by Response Surface Methodology. International Journal of Food Engineering, 15(8), 20190085.

Publisher's Note Springer Nature remains neutral with regard to jurisdictional claims in published maps and institutional affiliations. 